Research Article

\title{
Genotoxic evaluation of an industrial effluent from an oil refinery using plant and animal bioassays
}

Fernando Postalli Rodrigues ${ }^{1}$, José Pedro Friedmann Angeli ${ }^{1}$, Mário Sérgio Mantovani ${ }^{1}$, Carmen Luisa Barbosa Guedes $^{2}$ and Berenice Quinzani Jordão ${ }^{1}$

${ }^{1}$ Departamento de Biologia Geral, Centro de Ciências Biológicas, Universidade Estadual de Londrina, Londrina, PR, Brazil.

${ }^{2}$ Laboratório de Fluorescência e Ressonância Paramagnética Eletrônica, Departamento de Química, Centro de Ciências Exatas, Universidade Estadual de Londrina, Londrina, PR, Brazil.

\begin{abstract}
Polycyclic aromatic hydrocarbons (PAHs) are genotoxic chemicals commonly found in effluents from oil refineries. Bioassays using plants and cells cultures can be employed for assessing environmental safety and potential genotoxicity. In this study, the genotoxic potential of an oil refinery effluent was analyzed by means of micronucleus (MN) testing of Alium cepa, which revealed no effect after $24 \mathrm{~h}$ of treatment. On the other hand, primary lesions in the DNA of rat (Rattus norvegicus) hepatoma cells (HTC) were observed through comet assaying after only $2 \mathrm{~h}$ of exposure. On considering the capacity to detect DNA damage of a different nature and of these cells to metabolize xenobiotics, we suggest the association of the two bioassays with these cell types, plant (Allium cepa) and mammal (HTC) cells, for more accurately assessing genotoxicity in environmental samples.
\end{abstract}

Key words: Allium cepa, HTC cells, micronucleus, comet assay, petroleum waste disposal.

Received: January 22, 2009; Accepted: August 24, 2009.

\section{Introduction}

Genetic toxicology is a multidisciplinar field of research involved in detecting compounds capable of causing DNA damage and/or protecting DNA, with the aim of understanding potential biological consequences and molecular mechanisms of genetic material (Uhl et al., 2003).

DNA noxious compounds are produced on a large scale by the secondary sector of world economy, this including the petrochemical industry through oil refining and related processes. This generally comprises heavy metals and organic compounds, as for example, mono- and polyaromatic hydrocarbons, and chlorinated and phosphorylated besides other contaminants, such as sulfuric acid (Houk, 1992; Ohe et al., 2004). According to the Toxic Release Inventory (EPA) report of 2005, in the United States, the oil refining industry is one of 10 major sources emitting toxic chemicals into the environment.

Short-term biological assays have been widely used for evaluating environmental samples (Mitchelmore and Chipman, 1998; Avishai et al., 2002; Klobucar et al., 2003). By means of cytogenetic studies in higher plants, it

Send Correspondece to Fernando Postalli Rodrigues. Departamento de Biologia Geral, Centro de Ciências Biológicas, Universidade Estadual de Londrina, 86951-990 Londrina, PR, Brazil. E-mail: ferpostalli@ hotmail.com; ferpostalli@usp.br. is now possible to define chromosomal alterations and changes in in vivo cell proliferation, an example being the micronucleus test with Allium cepa developed by Evans et al. (1959). Thus, the clastogenic effect of polluted waters can be defined with considerable reliability (Ma et al., 1995; Chandra et al., 2005; Majer et al., 2005; Srivastava et al., 2005).

On the other hand, in vitro systems have proved to be more susceptible to the standardization of experimental conditions, availability and facile reproducibility of results (Rabello-Gay et al., 1991). Its application provides for effective environmental sample analysis, such as the cytotoxicity assay employing fish primary epithelial cell cultures for defining the aquatic pollutants copper and prochloraz (Dowling and Mothersill, 2001), and the comet assay as applied to the RTH-149 fish hepatoma cell line (Avishai et al., 2002). The comet assay itself appears to be an ideal tool in toxicological studies (Kuroda et al., 1992; Avishai et al., 2002), through being a rapid, simple, sensitive and relatively inexpensive method for detecting and analyzing DNA breaks in individual cells (Singh et al., 1988; Speit and Hartmann, 1999; Brendler-Schwaad et al., 2005).

There are few studies in which environmental samples have been tested by way of various assays simultaneously, thereby affording the means for comparing the 
sensitivity of different test-systems (Uhl et al., 2003). Here, the genotoxicity of an effluent from an oil refinery was determined in vivo by the MN test in Allium cepa, and in vitro by the comet assay in HTC metabolizing cells. The results thus obtained were mutually compared.

\section{Materials and Methods}

\section{Cell line}

HTC rat hepatoma cells were acquired from the Rio de Janeiro Cell Bank. Cells were grown in a DMEM/F-12 medium (Gibco), supplemented with 10\% fetal bovine serum (FBS, Gibco) as monolayer in $25 \mathrm{~cm}^{2}$ flasks, in a BOD type incubator at $37{ }^{\circ} \mathrm{C}$. Under these conditions, the doubling time was approximately $24 \mathrm{~h}$ for HTC.

\section{Characterization of the effluent}

The effluent from an oil refinery was used for testing. Both the removal of solids and colloids and the subsequent biological treatment were undertaken on the spot. Initial physic-chemical properties were: $\mathrm{pH} 6.25$; dissolved oxygen $=6.20 \mathrm{mg} \mathrm{O}_{2} / \mathrm{L}$; conductivity $=1242 \mu \mathrm{S} / \mathrm{cm}$; temperature $=23{ }^{\circ} \mathrm{C}$; total organic carbon $=20.07 \mathrm{ppm}$; and biochemical oxygen demand $=81.24 \mathrm{ppm}$. A complementary test was carried out to determine total phenols in the effluent by means of 4-aminoantipyrine in an alkaline medium and measuring absorbance in a FENTO model 482 spectrophotometer at $460 \mathrm{~nm}$ (AWWA, 1999).

Parameter temperatures, dissolved oxygen and water conductivity were continuously monitored throughout the experiments.

\section{Micronucleus (MN) testing and determination of cell proliferation in Allium cepa}

The method applied to MN testing in Allium cepa (common onion), with minor modifications, has already been described by Ma (1995). Prior to treatments, onion bulbs were cleaned to remove dried outer layers, washed in running water, and then partially submersed. Primordial root tissue was then allowed to grow for $48 \mathrm{~h}$ in a BOD type incubator at $25 \pm 0.5^{\circ} \mathrm{C}$. Those displaying root growth of less than $2 \mathrm{~cm}$ were discarded. Sequentially, 3 bulbs were exposed for $24 \mathrm{~h}$ to each of the following effluent concentrations: 25,50 and $100 \%$. Well water without chlorine used to dilute the effluent was the negative control, whereas methylmethane sulfonate (MMS) dissolved in well water at $10 \mathrm{mg} / \mathrm{mL}$, was the positive. During the entire assay, the bulbs were kept in the dark at a constant temperature of $25^{\circ} \mathrm{C}$. In each treatment, 5 randomly chosen roots from each bulb, and stained with aceto-chloride orcein according to the Tjio and Levan (1950) method, were used to prepare 5 slides. Subsequently, 5000 cells obtained from that portion of the root tip adjacent to the meristem ( $\mathrm{F} 1$ generation of cells) were analyzed (1000 cells/slide). MN frequency was obtained by dividing the number of cells with $\mathrm{MN}$ by the number of cells analyzed in each treatment, and multiplying by 100 . Furthermore, the mitotic index (MI) was defined by examining 5000 meristematic cells per treatment (1000/root), and was expressed as a percentage of cells in mitosis in all the evaluated meristematic cells.

\section{Comet assay in hepatoma cells (HTC)}

The comet assay was applied using Rattus norvegicus hepatoma cells (HTC), according to the protocol described by Uhl et al. (1999, 2000), and following the premise proposed by Tice et al. (2000). HTC cells were grown in a DMEM F12 medium for $24 \mathrm{~h}$ prior to treatment. Subsequently, the culture medium was discarded and the cells were washed with PBS ( $\mathrm{pH}$ 7.4). All the treatments were applied directly to cells for $2 \mathrm{~h}$, with three repetitions each. The experimental protocols were: a) treatments with a culture medium prepared with 25,50 and $100 \%$ of effluent diluted with water, where the concentration of the medium (0.468 g DMEM-F12 per $\mathrm{mL}$ ) was the same for all; b) positive control with benzo[a]pyrene added at $10 \mu \mathrm{g} / \mathrm{mL}$ in the culture medium; and c) negative control with the culture medium.

Finally, cells were harvested by trypsinization using $0.5 \mathrm{~mL}$ of $0.025 \%$ trypsin and $0.5 \mathrm{~mL}$ PBS (pH 7.4), whereupon a small sample was employed for testing cytotoxicity by the trypan blue exclusion method. A $20 \mu \mathrm{L}$ aliquot of the cell suspension was embedded in low melting-point agarose $(120 \mu \mathrm{L})$, and then spread onto a slide previously coated with normal melting-point agarose. Next, the cells were submersed in a lysis solution $(1 \mathrm{~mL}$ of Triton X-100, $10 \mathrm{~mL}$ of DMSO and $89 \mathrm{~mL}$ of lysis stock solution, $\mathrm{pH} 10.0$ - lysis stock solution: $146.1 \mathrm{~g}$ of $\mathrm{NaCl}(2.5 \mathrm{M}), 37.2 \mathrm{~g}$ of EDTA $(100 \mathrm{mM}), 1.2 \mathrm{~g}$ of Tris $(10 \mathrm{mM}), \sim 8.0 \mathrm{~g}$ of solid $\mathrm{NaOH}, 890 \mathrm{~mL}$ of distilled $\mathrm{H}_{2} \mathrm{O}$ and $10 \mathrm{~g}$ of sodium lauryl sarcosinate), where they were left overnight. Electrophoresis was then carried out at $\mathrm{pH}>13.0(30 \mathrm{~mL}$ of $10 \mathrm{~N} \mathrm{NaOH}$, $5 \mathrm{~mL}$ of $200 \mathrm{mM}$ EDTA - $\mathrm{pH} 10.0$ and double-distilled $\mathrm{H}_{2} \mathrm{O}$ added to complete $1000 \mathrm{~mL}$ ); gels were run for $20 \mathrm{~min}$ at $300 \mathrm{~mA}$ and $\sim 0.8 \mathrm{~V} / \mathrm{cm}$, preceded by 20 min submersion in buffer to denature DNA. After electrophoresis, the cells were neutralized ( $48.5 \mathrm{~g}$ of Tris in distilled $\mathrm{H}_{2} \mathrm{O}$ to a final volume of $1000 \mathrm{~mL}$ and a final concentration of $0.4 \mathrm{M}$, $\mathrm{pH}$ 7.5), and then fixed in absolute ethanol (10 min). The slides were stained with ethidium bromide $(0.02 \mathrm{mg} / \mathrm{mL})$ at the moment of analysis, using a NIKON fluorescence microscope with a B-3A filter (excitation of $\lambda=520 \mathrm{~nm}$ ) and $40 \mathrm{X}$ objective.

Each treatment was independently repeated threefold. In each case, 100 cells were examined microscopically (Kobayashi et al. 1995), and classified according to the following criteria: class 0 - cells with undetectable damage, in which no tail was visible; class 1 - cells with a tail shorter than the diameter of the nucleus; class 2 - cells with a tail longer than and up to twice the diameter of the nucleus; and class 3 - cells with a tail longer than twice the di- 
ameter of the nucleus. Apoptotic cells, wherein the nucleus was totally fragmented, were not taken into consideration in the analysis (Speit and Hartmann, 2005). The comet assay was carried out only in treatments in which cellular viability was greater than $80 \%$, as determined by the trypan blue exclusion assay.

\section{Statistical analysis of the data}

The results obtained by comet assaying of HTC cells were evaluated by the Jandel Scientific Sigma Stat 2.0 program through analyzing the variance of means (ANOVA). The Kruskall-Wallis test (ANOVA), followed by the Tukey test for multiple comparison of means $(\alpha=0.05$ and $\alpha=0.001$ ), were used in the case of MN and MI data in Allium cepa.

\section{Results}

\section{Characteristics of the effluent - Determination of chemical and total phenolic constituents and physico-chemical parameters}

The physico-chemical parameters of the effluents after periods of treatment and negative control were monitored throughout the experiment. Values (means \pm SD) remained stable during experiments for conductivity, with the following results for control: temperature = $22.75 \pm 0.5{ }^{\circ} \mathrm{C} ; \mathrm{pH}=8.23 \pm 0.04$; dissolved oxygen $=$ $7.94 \pm 0.1 \mathrm{mg} \quad \mathrm{O}_{2} / \mathrm{L} ;$ and conductivity $=$ $186.25 \pm 4.65 \mu \mathrm{S} / \mathrm{cm}$. The results with effluents were: temperature $=22.75 \pm 0.5^{\circ} \mathrm{C} ; \mathrm{pH}=7.83 \pm 0.14$; dissolved oxygen $=7.71 \pm 0.24 \mathrm{mg} \mathrm{O} / \mathrm{L} ;$ and conductivity $=$ $1957.33 \pm 0.58 \mu \mathrm{S} / \mathrm{cm}$. The concentration of total phenols in the effluent was $24 \mu \mathrm{g} / \mathrm{L}$. Other organic compounds detected are shown in Table 1.

\section{MN test in Allium cepa}

The values obtained for the parameters analyzed in the root tip cells of Allium cepa are shown in Table 2. Effluent concentrations of 25,50 and $100 \%$ did not induce the formation of MNs in F1 generation root cells at a frequency that differed significantly from the negative control. In relation to MMS results (positive control), the frequency of $\mathrm{MNs}$ in cells exposed to the effluent were significantly lower. Similarly, it was observed that there were no significant differences in mitotic index (MI) means values for any of the effluent concentrations tested versus negative control $(\mathrm{p}>0.05)$.

\section{Comet assay in HTC cells}

The results obtained with this bioassay are presented in Figure 1. Higher concentrations (50 and 100\%) caused an increase in DNA damage, whereas at $25 \%$, there was no alteration in DNA migration patterns. Cell viability remain-
Table 1 - Mono-aromatic and poly-aromatic compounds present in the effluent.

\begin{tabular}{lc}
\hline Hydrocarbon & $\mathrm{ppb}^{1}$ \\
\hline Mono-aromatic & \\
Toluene & 75 \\
Ethylbenzene & 126 \\
Xylene & 85 \\
Poly-aromatic & \\
Pyrene & 9 \\
Benzo(a)antracene & 33 \\
Benzo(a)pyrene & 61 \\
\hline
\end{tabular}

${ }^{1} \mathrm{ppb}=$ parts per billion.

Table 2 - Occurrence of micronuclei in F1 cells and mitotic indices in Allium cepa.

\begin{tabular}{lccc}
\hline \multicolumn{2}{c}{ Exposure $(24 \mathrm{~h})$} & Mean MN $(\% \pm \mathrm{SD})$ & Mean MI $(\% \pm \mathrm{SD})$ \\
\hline \multirow{3}{*}{ Effluent } & $100 \%$ & $1.6 \pm 1$ & $18.44 \pm 1.5$ \\
& $50 \%$ & $1.4 \pm 0.5$ & $16.74 \pm 3.5$ \\
& $25 \%$ & $1.4 \pm 1$ & $16.48 \pm 1.8$ \\
\hline Water & $1.2 \pm 0.5$ & $17.74 \pm 1.9$ \\
\hline MMS & & $4.0 \pm 1 *$ & $15 \pm 3.9$ \\
\hline
\end{tabular}

Mean values: $\%$ in 5000 cells/treatment; $\mathrm{MN}=$ micronucleus; $\mathrm{MI}=$ mitotic index; $\mathrm{SD}=$ standard deviation. ${ }^{*}=$ significant difference in relation to all the other samples $(\mathrm{p}>0.05)$.

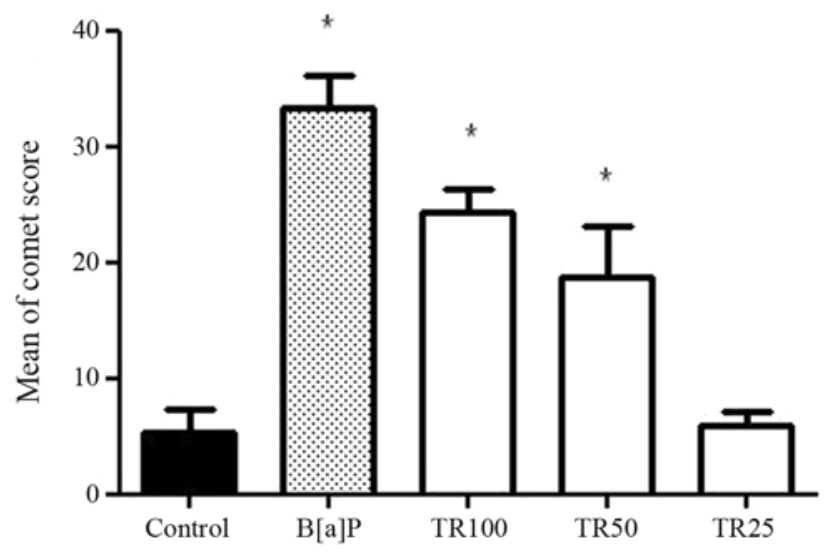

Figure 1 - Mean scores of DNA damage in HTC cells. The values were obtained by summing up the number of cells identified in each class of damage and multiplying by the value of the particular class (from 1 to 3 ). The averages were calculated from reckoning 100 cells per treatment. TR $100=$ treatment with $100 \%$ of effluent; TR $50=$ treatment with $50 \%$ of effluent; and TR25 = treatment with $25 \%$ of effluent. B[a]p = Benzo[a]pyrene; control $=$ water. ${ }^{*}=$ significantly different in relation to control $(\mathrm{p}>0.05)$.

ing higher than $90 \%$ in all treatments indicated non-cytotoxity in tested concentrations.

\section{Discussion}

An oil refinery effluent was tested for its mutagenic and genotoxic potential through micronucleus (MN) testing 
in Allium cepa and comet-assaying in a rat hepatoma cell line (HTC). As in vitro assays are proposed for the detection of environmental mutagenic agents (Kuroda et al. 1992), so bioassays with plants are also recommended for investigating compounds present in environmental samples and which cause genetic instability in DNA (Ma et al., 1983; Plewa and Wagner, 1993; Rodrigues et al., 1997). Allium cepa has proved to be an effective in vivo experimental model for determining both the toxic and genotoxic effects of substances and complex mixtures. On the other hand, HTC cells, due to their origin-tissue, are proficient in the metabolism of xenobiotics.

According to EPA (2005), in the United States, industries involved in refining petroleum products are among the most profuse emitters of toxic chemicals into the environment. Waste disposal therefrom has been shown to be highly toxic, often due to the soluble part, which contains inorganic (e.g., salts and heavy metals) and organic (e.g., oils, fats, PAHs and BTEX) compounds (Claxton et al., 1998; Almeida-Val et al., 2002). Chemical analysis of the effluent under study demonstrated the presence of various organic, including aromatic, substances, viz., toluene, ethylbenzene, xylene, pyrene, benzo[a]anthracene, benzo[a]pyrene and phenolic compounds. Although these were detected at lower concentrations than the limit allowed for the discharge of industrial effluents into water bodies (CONAMA - National Council of Environment [2005]. Definition on water classification - CONAMA, 357. Brazil.), there are always risks associated with exposure at low concentrations (Ostergaard et al., 2007).

The history of aromatic chemicals, as for example polyaromatic hydrocarbons (PAHs), demonstrates a relationship between the appearance of tumors in fishes and their presence in the water and sediment (Stein et al., 1990; Myers et al., 1991), thereby evinving their carcinogenic properties (Stalker et al., 1991; Pacheco and Santos, 2001; White, 2002; Cebulska-Wasilewska et al., 2005). Among the PAHs, nitropyrene and benzo[a]pyrene $(\mathrm{B}[\mathrm{a}] \mathrm{p})$ are capable of forming DNA adducts after metabolic activation, this occuring in vertebrates (Roy et al., 1989), more commonly in fishes, through their possessing a cytochrome $\mathrm{P}-450$ system which is very active in this process (Smolarek et al., 1987; Varanasi et al., 1989; Sikka et al. 1991; Mitchelmore and Chipman, 1998).

Although considered one of the most potent mutagens, the PAHs encountered in the effluent studied were incapable of inducing MN formation in Allium cepa $\mathrm{F} 1$ cells, as was also demonstrated in other studies with plants (Veleminsky and Gichner, 1988). On the other hand, comet assaying indicated detectable DNA damage in HTCs. As it is known that PAH metabolism in humans and other mammals is complex (Scicchitano, 2005), and that HTCs are proficient in metabolizing these xenobiotics, this appears to be a likely explanation of the positive results observed.
The most important aspect in the understanding of these results appears to be that of PAHs acting indirectly on DNA. In other words, they need to be metabolically activated to be able to cause damage, this requiring the production of electrophilic metabolites by the cytochrome P450 system of phase I metabolism in the detoxification process (Cohen and Rice, 2001; Lee and Steinert, 2003). Thus, one must consider that higher plants also possess a cytochrome P450 system involved in detoxification processes (Werc et al., 1990; Sanderman, 1992; Guencheva and Henriques, 2003), which would make Allium cepa an appropriate test organism for the analysis of the biotransformation of these chemical compounds. However, Plewa and Wagner (1993) reported that direct exposure to indirect-acting compounds in plants has proved to be of little effect. Related studies have raised the question as to whether plants can be used for detecting compounds that cause DNA damage and cancer in humans (Plewa and Wagner, 1993). This extrapolation depends directly on whether plants have a metabolizing system similar to that found in animals. However, Higashi (1988) and Sanderman (1992) found that plant cells contain active enzymes of the cytochrome P450 system, but at much lower activity levels than in rodents and humans. Moreover, their specific substrates differ substantially from those in mammals. Thus, the absence of mutagenic effects in Allium cepa, as observed in the present study, could be associated with the lower activity of the biotransforming system of xenobiotics in these root cells, as well as with the low quantity of aromatic compounds in the effluent. Uhl et al. (2003) observed the relative insensitivity of bioassays with plants to environmental contaminants, including PAHs, when these are dispersed in the environment and occur at relatively low concentrations.

Phenols were also present in the effluent in question. According to Spencer et al. (2007), these significantly increase the number of micronuclei in rats. Mitteregger et al. (2007) demonstrated toxicity in Allium cepa after exposure to environmental samples of water and sediment containing phenolic compounds. In the present study, on the contrary, even with an increase in $\mathrm{MN}$ in $A$. cepa, no toxic effects were revealed in cell proliferation assessment in the form of a decrease in cell growth (MI). On the other hand, Huang et al. (2007), by using the comet assay, also reported a positive and significant correlation between DNA damage in the liver of frogs (Bufo raddei) and the concentration of oil and/or phenol present from nearby petroleum plants. The DNA damage found in HTC cells could also be attributed to phenols present in the effluent. Further consideration should also be given to the monoaromatic compounds, benzene, toluene and ethylbenzene, detected in the effluent from the refinery under study. These were held responsible for the mutagenic effects detected in some cases reviewed by Ohe et al. (2004), when applying the Ames test, as well as other in vitro assays with bacterial, fungal, plant and animal cells. Likewise, these agents may have contributed to 
the in vitro genotoxic damage observed in the present study.

It is also common to find genotoxic agents in the form of heavy metals, in effluents from oil refining. In this study, the effluent was not assayed for these. Nevertheless, further investigation showed that there was induced DNA damage detected in vivo through comet assaying, and which gradually and rapidly underwent repair in its absence (data not shown), thereby implying no cellular accumulation of heavy metals. This observation further reinforces the notion of the preponderant role of effluent aromatic compounds in the genotoxic damage detected in HTC cells.

Nevertheless, according to Houk (1992), environmental samples should always be primarily evaluated as being a mixture of chemical compounds which may or may not interact with each other synergistically, additively or antagonistically, thereby generating a noxious effect.

An analysis of the present results also led us to consider that the diverse cellular responses obtained with comet assaying in HTC cells, as compared to MN testing in Allium cepa could even be attributed to the different end points contemplated (Guterres et al., 2005). Cometassaying detects DNA strand-breaks and alkali-labile sites, among other primary lesions that could be repaired (Tice, 2000). On the other hand, micronucleus testing detects lesions that have not been repaired, thereby becoming permanent after one cell-cycle (Rabello-Gay et al., 1991), or rather, clastogenic effects that result in chromosomal breakage and/or aneugenic effects, thus terminating in alterations in chromosomal anchorage to the mitotic spindle. In the present study, there was insufficient time for the possible repair of lesions caused by the treatments in HTC cells, since the cells were harvested immediately after the exposure period and submitted at once to the comet assay protocol. Therefore, it is likely that primary lesions formed would be detected. However, in Allium cepa MN assaying it is believed that if the test substance produced DNA adducts, these lesions did not lead to those chromosomal breaks that give rise to micronuclei.

The results reinforce the idea that the use of various experimental protocols with regard to the type of assay, cell exposure time and the type of cells employed, can lead to a better determination of the mechanism of toxicity of a mixture (Kuroda et al., 1992), since diverse mechanisms and parameters are involved in different genotoxicity tests (Zhong et al., (2001).

Thus, although it is difficult to tell which of the chemical components identified and quantified in the effluent studied caused the detected damage, the results do indicate that the main genotoxic agents in this industrial wastewater are xenobiotic-metabolizing dependent aromatic hydrocarbons, which exerted no detrimental effect on the plant cells employed. If DNA lesions did in fact occur in these cells, they did not occasion chromosomal alterations leading to the occurrence of micronuclei in the F1 cells.

\section{Acknowledgments}

This study was supported by CNPq, CAPES and Fundação Araucária, Brazil. Dr. A. Leyva helped with English editing of the manuscript.

\section{References}

Almeida-Val VMF, Duncan WP and Val AL (2002) Crude oil effects on fish of the Amazon: Current Status. In: Val AL, Almeida-Val VMF and McKinley D (eds) Tropical Fish: News and Reviews. International Congress on the Biology of Fish. University of British Columbia, Vancouver, pp 49.

Avishai N, Rabinowitz C, Moiseeva E and Rinkevich B (2002) Genotoxicity of the Kishon River, Israel: The application of an in vitro cellular assay. Mutat Res 518:21-37.

AWWA-American Water Works Association (1999) Method 5530c: Chloroform extraction method. In: Clesceri LS, Greenberg AE and Eaton AD (eds) Standard Methods for the Examination of Water and Wastewater. $20^{\text {th }}$ edition. American Public Health Association and American Water Works Association, Water Environmental Federation, Washington DC, pp 42-43.

Brendler-Schwaad S, Hartmann A, Pfuhler S and Speit G (2005) The in vivo comet assay: Use and status in genotoxicity testing. Mutagenesis 20:245-254.

Cebulska-Wasilewska A, Wieche CA, Panek A, Binkov AB, Radim J, Peter S and Farmer B (2005) Influence of environmental exposure to PAHs on the susceptibility of lymphocytes to DNA-damage induction and on their repair capacity. Mutat Res 588:73-81.

Chandra S, Chauhan LKS, Murthy RC, Saxena PN, Pande PN and Gupta SK (2005) Comparative biomonitoring of leachates from hazardous solid waste of two industries using Allium test. Sci Tot Environ 347:46-52.

Claxton LD, Houk VS and Hughes TJ (1998) Genotoxicity of industrial wastes and effluents. Mutat Res 410:237-243.

Cohen DE and Rice RH (2001) Toxic responses of the skin. In: Klaassen CD (ed) Toxicology the Basic Science of Poisons. $6^{\text {th }}$ edition. McGraw-Hill Companies, New York, pp 653671.

Dowling K and Mothersill C (2001) The further development of rainbow trout primary epithelial cell cultures as a diagnostic tool in ecotoxicology risk assessment. Aquat Toxicol $53: 279-289$

Evans HJ, Neary GJ and Williamson F (1959) The relative biological efficiency of single doses of fast neutrons and gammarays on Vicia faba roots and the effect of oxygen. Part II. Chromosome damage: The production of micronuclei. Int $\mathbf{J}$ Rad Biol 3:216-229.

Guencheva TN and Henriques JAP (2003) Metabolismo de xenobióticos. Citocromo P450. In: Da Silva J, Erdtman B and Pegas Henriques JA (eds) Genética Toxicológica. Alcance, Brazil, pp 225-243.

Guterres ZR, Mantovani MS, Eira AF, Ribeiro LR and Jordão BQ (2005) Genotoxic and antigenotoxic effects of organic extracts of mushroom Agaricus blazei Murrill on V79 cells. Genet Mol Biol 28:458-463.

Higashi K (1988) Metabolic activation of environmental chemicals by microsomal enzymes of higher plants. Mutat Res 197:273-288. 
Houk VS (1992) The genotoxicity of industrial wastes and effluents - A review. Mutat Res 277:91-138.

Huang D, Zhang Y, Wang Y, Xi Z and Ji W (2007) Assessment of the genotoxicity in toad Bufo raddei exposed to petrochemical contaminants in Lanzhou Region, China. Mutat Res 629:81-88.

Klobucar GIVM, Pavlica M, Erben R and Papes D (2003) Application of the micronucleus and comet assays to mussel Dreissena polymorpha haemocytes for genotoxicity monitoring of freshwater environments. Aquat Toxicol 64:15-23.

Kobayashi H, Sugiyama C, Morikawa Y, Hayashi M and Sofuni T (1995) A comparison between the manual microscopic analysis and computerized image analysis in the single cell gel electrophoresis. MMS Commun 3:103-115.

Kuroda Y, Jain AK, Tezuka H and Kada T (1992) Antimutagenicity in cultured mammalian cells. Mutat Res 267:201-209.

Lee RF and Steinert S (2003) Use of the single cell gel electrophoresis/comet assay for detecting DNA damage in aquatic (marine and freshwater) animals. Mutat Res 544:43-64.

Ma TH, Anderson VA, Harris MM and Bare JL (1983) Tradescantia-Micronucleus (Trad-MCN) test on the genotoxicity of malathion. Environ Mutagen 5:127-137.

Ma TH, Xu Z, Xu C, Mcconnell H, Rabago EV, Arreola GA and Zhang H (1995) The improved Allium/Vicia root tip micronucleus assay for clastogenicity of environmental pollutants. Mutat Res 334:185-195.

Majer BJ, Grummt T, Uhl M and Knasmüller S (2005) Use of plant bioassays for the detection of genotoxins in the aquatic environment. Acta Hydrochim Hydrobiol 33:45-55.

Mitchelmore CL and Chipman JK (1998) DNA strand breakage in aquatic organisms and the potential value of the comet assay in environmental monitoring. Mutat Res 399:135-147.

Mitteregger JRH, Silva J, Arenzon A, Portela CS, De Sá ICF and Henriques JAP (2007) Evaluation of genotoxicity and toxicity of water and sediment samples from a Brazilian stream influenced by tannery industries. Chemosphere 67:12111217.

Myers MS, Landahl JT, Krahn MM and Mcc BB (1991) Relationship between hepatic neoplasm and related lesions and exposure to toxic chemicals in marine fish from the US West Coast. Environ Health Perspect 90:7-15.

Ohe T, Watanabeb T and Wakabayashi K (2004) Mutagens in surface waters: A review. Mutat Res 567:109-149.

Ostergaard TG, Hansen LH, Binderup M, Norman A and Sorensen SJ (2007) The $c d a$ GenoTox assay: A new and sensitive method for detection of environmental genotoxins, including nitroamines and aromatic amines. Mutat Res 631:77-84.

Pacheco M and Santos AM (2001) Biotransformation, endocrine, and genetic responses of Anguilla anguilla L. to petroleum distillate products and environmentally contaminated waters. Ecotoxicol Environ Saf 49:64-75.

Plewa MJ and Wagner ED (1993) Activation of promutagens by green plants. Annu Rev Genet 27:93-113.

Rabello-Gay M, Rodrigues MAR and Monteleone-Neto R (eds) (1991) Mutagênese, Teratogênese e Carcinogênese: Métodos e Critérios de avaliação. Sociedade Brasileira de Genética, Ribeirão Preto, 241 pp.

Rodrigues GS, Ma TH, Pimental D and Weinstein LH (1997) Tradescantia bioassays as monitoring systems for environmental mutagenesis: A Review. Crit Rev Plant Sci 16:325-359.
Roy AK, El-Bayoumy K and Hecht SS (1989) 32P-postlabeling analysis of 1-nitropyrene-DNA adducts in female SpragueDawley rats. Carcinogenesis 10:195-198.

Sandermann H (1992) Plant metabolism of xenobiotics. Trends Biochem Sci 17:82-84.

Scicchitano DA (2005) Transcription past DNA adducts derived from polycyclic aromatic hydrocarbons. Mutat Res 577:146-154.

Sikka HC, Steward AR, Kandaswani C, Rutkowski JP, Zaleski J, Kumar S, Earley K and Gupta RC (1991) Metabolism of benzo(a)pyrene and persistence of DNA adducts in the brown bullhead (Ictalurus nebulosus). Comp Biochem Physiol 100:25-28.

Singh NP, Mccoy MT, Tice RR and Schneider EL (1988) A simple technique for quantification of low levels of DNA damage in individual cells. Exp Cell Res 175:184-191.

Smolarek TA, Morgan SL, Moynihan CG, Lee H, Harvey RG and Baird WM (1987) Metabolism and DNA adduct formation of benzo(a)pyrene and 7,12-dimethylbenz(a)anthracene in fish cell lines in culture. Carcinogenesis 8:1501-1509.

Speit G and Hartmann A (1999) The comet assay (single-cell gel test) - A sensitive genotoxicity test for the detection of DNA damage and repair. In: Henderson DS (ed) Methods in Molecular Biology, DNA Repair Protocols: Eucaryotic Systems. Humana Press, Totowa, pp 203-212.

Speit G and Hartmann A (2005) The comet assay: A sensitive genotoxicity test for the detection of DNA damage. Meth Mol Biol 291:85-95.

Spencer PJ, Gollapudi BB and Waechter Jr JM (2007) Induction of micronuclei by phenol in the mouse bone marrow: I. Association with chemically induced hypothermia. Toxicol Sci 97:120-127.

Srivastava R, Kumar D and Gupta SK (2005) Bioremediation of municipal sludge by vermitechnology and toxicity assessment by Allium cepa. Bioresour Technol 96:1867-1871.

Stalker MJ, Kirby GM, Kocal TE, Smith IR and Hayes MA (1991) Loss of glutathione S-transferases in pollution-associated liver neoplasms in white suckers (Catostomus commersoni) from Lake Ontario. Carcinogenesis 12:2221-2226.

Stein JE, Reichert WL, Nishimoto M and Varanasi U (1990) Overview of studies on liver carcinogenesis in English sole from Puget Sound: Evidence for a xenobiotic chemical etiology. Biochemical studies. Sci Tot Environ 94:51-69.

Tice RR, Agurell E, Anderson D, Burlinson B, Hartmann A, Kobayashi H, Miyamae Y, Rojas E, Ryu JC and Sasaki YF (2000) The single cell gel/comet assay: Guidelines for in vitro and in vivo genetic toxicology testing. Environ Mol Mutagen 35:206-221.

Tjio JH and Levan A (1950) The use the oxyquinoline in chromosome analysis. Ann Est Exp 2:21-64.

Uhl M, Helma C and Knasmuller S (1999) Single cell gel electrophoresis assay with human-derived hepatoma (HepG2) cells. Mutat Res 441:215-224.

Uhl M, Helma C and Knasmuller S (2000) Evaluation of the single cell gel electrophoresis assay with human hepatoma (HepG2) cells. Mutat Res 468:213-225.

Uhl M, Plewa MJ, Majer BJ and Knasmüller S (2003) Basic principles of genetic toxicology with an emphasis on plant bioassays. In: Maluszynska J and Plewa M (eds) Bioassays in Plant Cells for Improvement of Ecosystem and human Health: A course manual. Katowice, Poland, pp 11-30. 
Varanasi U, Reichert WL, Leeberhart BT and Stein JE (1989) Formation and persistence of benzo(a)pyrene-diol epoxideDNA adducts in liver of English sole (Parophrys vetulus). Chem Biol Interact 69:203-216.

Veleminsky J and Gichner T (1988) Mutagenic activity of promutagens in plants: Indirect evidence of their activation. Mutat Res 197:221-242.

Werc RD, Gabriac B, Teustsch H and Durst F (1990) Two cytochrome $\mathrm{P} 450$ isoforms catalyzing O-deethylation of ethoxycoumarin and ethoxyresorufin in higher plants. Biochem $\mathrm{J}$ 270:729-735.

White PA (2002) The genotoxicity of priority polycyclic aromatic hydrocarbons in complex mixture. Mutat Res 515:85-98.
Zhong Y, Feng SL, Luo Y, Zhang GD and Kong ZM (2001) Evaluating the genotoxicity of surface water of Yangzhong city using the Vicia faba micronucleus test and the comet assay. Bull Environ Contam Toxicol 67:17-241.

\section{Internet Resources}

Environmental Protection Agency (EPA) http://www.epa.gov/triexplorer/industry.htm (November $12,2005)$.

Associate Editor: Catarina S. Takahashi

License information: This is an open-access article distributed under the terms of the Creative Commons Attribution License, which permits unrestricted use, distribution, and reproduction in any medium, provided the original work is properly cited. 